\title{
P01.38. Anti-cancer activity of extracts from Rauwolfia vomitoria and Pao Pereira
}

\author{
J Yu*, J Drisko, Q Chen \\ From International Research Congress on Integrative Medicine and Health 2012 \\ Portland, Oregon, USA. 15-18 May 2012
}

\section{Purpose}

To evaluate extracts from two medical plants Pao Pereira (Pao) and Rauwolfia vomitoria (Rau) for their antitumor effects in various types of pancreatic cancers and ovarian cancers.

\section{Methods}

Five pancreatic cancer and three ovarian cancer cell lines were tested that exhibited different resistance to the 1st line chemo-drug gemcitabine (Gem, for pancreatic cancer), and carboplatin ( $\mathrm{Cp}$, for ovarian cancer). Chou-Talalay's method was used to evaluate drug combination.

\section{Results}

Both Rau and Pao extracts induced dose-dependent cytotoxicities in all tested cancer cell lines, despite their inherent resistance to chemo-drugs. $\mathrm{IC}_{50}$ values for Rau were $140-350 \mu \mathrm{g} / \mathrm{ml}$, and $120-350 \mu \mathrm{g} / \mathrm{ml}$ for Pao, depending on the cells tested. Normal epithelial cell MRC-5 was much less affected compared to all the tested cancer cells. The differences of cell viabilities between cancer cells and normal cells were statistically significant $(\mathrm{p}<0.05)$, indicating possible low toxicity of these extracts. To test whether the treatments of Rau or Pao could enhance the cells' sensitivities to chemo-drugs, we combined either Rau or Pao with gemcitabine to treat pancreatic cancer cells, and with carboplatin to treat ovarian cancer cells. The combination treatments took Chou-Talalay's constant ratio design, with molar ratio set to $\mathrm{IC}_{50 \text { extract }}$ : $\mathrm{IC}_{50 \mathrm{Chemo}}$. The combined-treatments significantly enhanced cell death in cancer cells which were strongly resistant to gemcitabine or carboplatin $(\mathrm{p}<0.05)$. The results showed a left-shift in the doseresponse curves of the combination treatments

University of Kansas Medical Center, Kansas City, USA compared to the corresponding curves with either Gem or $\mathrm{Cp}$ alone in all tested cancer cells. Combination indices (CIs) were $<1$, indicating synergistic effects.

\section{Conclusion}

These results pave the way for in vivo studies of the anti-cancer effects of Rauwolfia vomitoria and Pao Pereira extracts, especially in gemcitabine-resistant pancreatic cancers and carboplatin-resistant ovarian cancers. Studies on mechanisms of the anti-cancer actions are also undergoing concerning apoptosis and cell cycle arrests.

Published: 12 June 2012

doi:10.1186/1472-6882-12-S1-P38

Cite this article as: Yu et al.: P01.38. Anti-cancer activity of extracts from Rauwolfia vomitoria and Pao Pereira. BMC Complementary and Alternative Medicine 2012 12(Suppl 1):P38.

Submit your next manuscript to BioMed Central and take full advantage of:

- Convenient online submission

- Thorough peer review

- No space constraints or color figure charges

- Immediate publication on acceptance

- Inclusion in PubMed, CAS, Scopus and Google Scholar

- Research which is freely available for redistribution (c) 2012 Yu et al; licensee BioMed Central Ltd. This is an Open Access article distributed under the terms of the Creative Commons Attribution License (http://creativecommons.org/licenses/by/2.0), which permits unrestricted use, distribution, and reproduction in any medium, provided the original work is properly cited. 